ARTICLE

\title{
COMPARATIVE ANALYSIS OF BIOGAS GENERATION FOR THE SOLID WASTE SECTOR USING UNMANNED AERIAL VEHICLE WITH THE BRAZILIAN MODEL OF GREENHOUSE GAS EMISSIONS IN AREAS WITH NO OPERATIONAL HISTORY
}

Análise comparativa da geração de biogás para o setor de resíduos sólidos utilizando Veiculo Aéreo não Tripulado com o modelo brasileiro de emissões de gases do efeito estufa em áreas sem histórico operacional

Gustavo Aiex Lopes ${ }^{1}$ - ORCID: 0000-0003-1752-7821

Thiago Simonato Mozer ${ }^{1}$

Ana Alice de Carli $^{1}$

${ }^{1}$ Universidade Federal Fluminense, Programa de Pós-graduação em Tecnologia Ambiental, Volta Redonda - Rio de Janeiro, Brasil.

E-mail: gustavoaiex@poli.ufri.br; thiagomozer@id.uff.br; anacarli@id.uff.br

Received in April 12 $2^{\text {th }}, 2017$.

Accepted in January $1^{\text {st }}, 2018$.

\section{Abstract:}

The city of Volta Redonda, located in the state of Rio de Janeiro, has a controlled landfill of municipal solid waste (MSW) which was partially recovered in 2008. This disposal site has no data on the amount of waste volume landfilled. An Unmanned Aerial Vehicle (UAV) was used to capture images of the study area and through Geographic Information Systems (GIS) the biogas generation was determined. By overlaying the georeferenced images the contour lines were determined which enabled the creation of the 3D Digital Terrain Model (DTM) of the area with a resolution of $0.296349 \mathrm{~m} / \mathrm{pix}$. The DTM provided the determination of the volume of waste landfilled $\left(535.755,79 \mathrm{~m}^{3}\right)$ and the real surface area $\left(36.770,96 \mathrm{~m}^{2}\right)$ of the controlled landfill. These parameters allowed obtainment the maximum flow rate of methane generation of $16.539,82 \mathrm{~m}^{3}$ for 2007. The Brazilian model used to determination biogas generation in waste sector achieve a maximum flow rate of methane generation of $126.599,4 \mathrm{~m}^{3}$ for the year 2007. A significant difference between biogas generation in the two models was observed mainly due to the amount of waste determined in both models.

Keywords: Biogas; Modeling; Controlled Landfill; Unmanned Aerial Vehicle; 3D Digital Terrain Model.

\section{Resumo:}

A cidade de Volta Redonda, localizada no estado do Rio de Janeiro, possui um aterro controlado de Resíduos Sólidos Municipais (RSM) que foi parcialmente recuperado em 2008. Este sítio de

How to cite this article: Lopes, G.A.; et al. Comparative analysis of biogas generation for the solid waste sector using Unmanned Aerial Vehicle with the Brazilian model of greenhouse gas emissions in areas with no operational history. Bulletin of Geodetic Sciences, Vol. 24, issue 1, 98-124, Jan-Mar, 2018. 
disposição não possui dados sobre a quantidade de volume de resíduos aterrados. Um veículo aéreo não tripulado (VANT) foi usado para capturar imagens da área de estudo e através de Sistemas de Informação Geográfica (GIS), foi determinada a geração de biogás. Ao sobrepor as imagens georreferenciadas foram determinadas as curvas de nível que possibilitaram a criação do Modelo Digital de Terreno 3D (MDT) da área com uma resolução de 0,296349 m / pix. O MDT proporcionou a determinação do volume de resíduos aterrados $\left(535.755,79 \mathrm{~m}^{3}\right)$ e da área de superfície real $\left(36.770,96 \mathrm{~m}^{2}\right)$ do aterro controlado. Estes parâmetros permitiram a obtenção da taxa de fluxo máximo de geração de metano de 16.539,82 $\mathrm{m}^{3}$ para 2007. O modelo brasileiro utilizado para a determinação da geração de biogás atingiu uma taxa de fluxo máximo de geração de 126.599,4 $\mathrm{m}^{3}$ para o ano de 2007. Uma diferença significativa entre a geração de biogás nos dois modelos foi observada, devido principalmente à quantidade de resíduos estimada nos dois modelos.

Palavras-chave: Biogás; Modelagem; Aterro Controlado; Veículo Aéreo não Tripulado; Modelo Digital de Terreno 3D.

\section{Introduction}

The disposition in the soil of Municipal Solid Waste (MSW) is still considered the most economic form of management adopted in almost all the countries of the world. Although there are other techniques which are more advantageous both energetically (e.g., incineration) and landfilled volume reduction (e.g. biological and mechanical treatment), wastes which are not reintroduced into the systems are preferably disposed of in landfills or other areas not controlled by the public administration (Emberton and Parker 1987; Calabrò et al. 2011; Barros et al. 2014; Wu et al. 2015).

MSW management depends mainly on structured plans and investments, a difficult issue in developing countries (Ejaz and Janjua 2012; Srivastava et al. 2015). It is important to consider that MSW irregular management of these activities causes negative environmental impacts. Local scale impacts such as contamination of soil, surface water and groundwater and on a global scale as emissions of greenhouse gases, mainly methane and carbon dioxide, are reported (El-Fadel et al. 2002; Atta et al. 2015; Wu et al. 2015).

The possibility of impacts occurs due to the formation of two specific effluents: landfill biogas and leachate.

The leachate and biogas characteristics are closely linked to the degradation phase of organic matter and are variable in time (El-Fadel et al. 2002; Wu et al. 2015; Chen, Knappe and Barlaz 2004; Di Bella et al. 2012). The qualitative aspects of leachate and biogas depend on the interaction of several factors such as: characteristics of MSW, climatic conditions, site-specific variables (e.g. type of cover soil, declivity) and design and operation of activities in the landfill. The identification of these characteristics is head for the development of the treatment systems to be adopted (Renou et al. 2008; Zairi, Aydi and Dhia 2014).

With the advent of the National Solid Waste Policy (NSWP) in Brazil, some forms of MSW management as open dump and controlled landfills are no longer allowed because they provide contamination and pollution. The new law framework required all municipalities in the country to adjust their MSW disposal areas and use the best waste treatment technology by the end of 2014, 
however, this time limit was extended to 2017 and 2021, as the size of the population of each municipality (Brasil 2010).

Brazilian legislation and the specific technical norms on MSW management present some terms that differ from those used in the literature, such as controlled landfill and open dump. Therefore, it is necessary to present the concepts. Open dump is a random area where MSW are placed on the soil without waterproofing, there are no capture and treatment systems for leachate and biogas and has no waste covering with earth or other inert material. The difference between an open dump and controlled landfill is that the MSW in the controlled landfill is covered with soil or other inert material at the end of each working day. The sanitary landfill is the correct form of disposal, presenting basic waterproofing, collection systems and treatment of biogas and leachate (ABNT 1985; ABNT 1992).

The NSWP also established the concept of an orphan area: contaminated or polluted area where it is not possible to identify the person responsible for the action. It should be noted that most open dump and controlled landfills are classified as orphan areas, thus becoming environmental liabilities of continental proportions, in which the responsibility for its remediation is to the public administration (Brasil 2010).

The current situation of MSW management in Brazil has evolved slowly and gradually between 2000 and 2014, indicating a 22.9\% increase in disposal in sanitary landfills and a drop of 15.1\% for disposal in open dump. The disposal in controlled landfills remained constant at around $24 \%$ of all the waste produced in the country during those years (ABRELPE 2015).

According to the National Sanitation Information System, 45 of the 92 cities in the state of Rio de Janeiro presented information on the MSW processing facility. Among the cities that submitted information, $53 \%$ operate landfills, $19 \%$ operate controlled landfills, and $28 \%$ have open dumps in operation. 33\% of controlled landfills in the state of Rio de Janeiro do not have basic waterproofing, $46 \%$ of controlled landfills do not have gas collection infrastructure, $72 \%$ of all treatment facility do not recover biogas, and $40 \%$ of all facility recirculate leachate. According to the Abrelpe report (2016) there are 3326 units of irregular disposal in Brazil, including open dumps and controlled landfills. The data presented in November 2016 reflect the reality of most Brazilian states and indicate the urgent need to mitigate environmental liabilities related to irregular disposal of MSW (SNIS 2016).

Within this context of contaminated and polluted remediation of areas it is observed that several mathematical models were developed to adequately estimate leachate flow rate (hydrological evaluation of landfill performance - HELP, adapted water balance, Darcy generalized law for liquids in porous media), gas generation (first-order kinetics reactions, biological degradation model combined with stochastic model of hydrological transport of contaminant and Moduelo 2) and to determine the best landfills siting (spatial multiple criteria analysis methodology, remote sensors combined with GIS and multicriteria spatial analysis) (Min et al. 2010; Camba et al. 2014; Feng et al. 2015; Manna, Zanetti and Genon 1999; Zacharof and Butler 2004; Cortázar and Monzón 2007; Kontos et al. 2005; Biotto et al. 2009).

Other models and tools have also been developed to facilitate data acquisition and environmental modeling; among them is the DTM, widely propagated in the last years. These models allow to better visualize and analyze the physical characteristics of an area. DTM can be described as a digital elevation model that encodes the topography through spatially georeferenced data. Aerial photographs and satellite imagery are processed automatically or semi-automatically to perform the extraction of contour lines and other morphological parameters (Toz and Erdogan 2008). 
It was also observed the evolution in the use of satellite images and remote sensing in different platforms, in addition to new technologies for determination of spatial characteristics that provide more accurate analyzes for different areas of knowledge as presented in Table 1.

Table 1: Different approaches to spatial analysis

\begin{tabular}{l|l}
\hline Issues addressed & References \\
\hline $\begin{array}{l}\text { evaluation of successional stages of vegetation } \\
\text { through satellite images }\end{array}$ & Sothe et al. (2017) \\
\hline $\begin{array}{l}\text { development of algorithms for improved land cover } \\
\text { classification using satellite images }\end{array}$ & Xiao et al. (2017) \\
\hline $\begin{array}{l}\text { photogrammetric observations for the aerial } \\
\text { triangulation process (LIDAR }{ }^{1} \text { system) }\end{array}$ & Debiasi and Mitishita (2013) \\
\hline $\begin{array}{l}\text { comparing the use of different variables and } \\
\text { classification algorithms for mapping (remote }\end{array}$ & Souza et al. (2016) \\
sensing) and monitoring of coffee growing areas. & \\
\hline $\begin{array}{l}\text { Evaluation of characteristics of submetric images } \\
\text { obtained with UAV for analysis of anthropic actions in } \\
\text { landscapes. }\end{array}$ & Ruiz et al. (2017) \\
\hline $\begin{array}{l}\text { volume calculation in a pile of waste using UAV,GNSS }{ }^{2} \\
\text { and LiDAR }\end{array}$ & Silva et al. 2016 \\
\hline $\begin{array}{l}\text { development of criteria that support the quality of } \\
\text { spatial data destined to the rural environmental } \\
\text { register using UAV }\end{array}$ & \\
\hline $\begin{array}{l}\text { mapping areas for analysis of border conflicts using } \\
\text { UAV al. (2017) }\end{array}$ & Graça et al. (2017) \\
\hline
\end{tabular}

Notes. 1: LIDAR - Light Detection And Ranging; 2: GNSS - Global Navigation Satellite System

Despite the evolution of the different models, a unique and low-cost methodology of data acquisition combining GIS - spatial analysis - remote sensing - leachate and biogas generation was not identified.

Without collection and treatment systems of leachate from landfills, this will contribute to the contamination and pollution of water and soil resources, while methane will contribute to the global climate change for approximately 80 years from the closure of the landfill (World Bank 2004).

Added to this scenario are the uncertainties of national estimates on greenhouse gas emissions in the MSW treatment sector, identified in the Second Brazilian Inventory of Emissions (uncertainties of $56 \%$ ) and in the third (uncertainties of $23 \%$ ). The calculations are subject to the defense due to model simplification and the influence in the biogas generation (MCT 2010; MCTI 2015). This model uses municipal solid waste characteristics and municipal solid waste per capita generation in a determined period of time. These input data produce uncertainties in the results.

The quantification of these effluents should be estimated as the starting point for any proposed recovery plan or treatment systems. Therefore the objective of this work is to present a combined methodology for quantifying the biogas flow rate of a controlled landfill that does not have 
operating data using a 3D digital elevation model. The use of digital cartographic products obtained with UAV to estimate landfills biogas is the main innovation of this research. The utilization of the geoprocessing tools was directed to the determination of MSW volume landfilled (one of the main input parameters in the model) and combined with other methods such kinetics of first-order reactions, which promoted the estimation of the biogas flow rate in a recovery area.

Another aim of this study is to compare the results obtained of biogas generation between the Brazilian model and the new methodology developed in a controlled landfill without operating records.

The final objective is to indicate a comparative analysis between data acquisition through an integrated methodology and conventional methodology for the development of plans for the management of degraded areas (environmental liabilities of the waste disposal sector).

\section{Material and Methods}

Three main parameters have been characterized: (i) MSW volume landfilled; (ii) landfill biogas generation for Scenario 1 and (iii) landfill biogas generation for Scenario 2. The first parameter has been independently modeled of the other two.

The amount of waste landfilled in the area for Scenario 1 was calculated using the per capita waste generation rate for the population of Volta Redonda from 1987 (start of disposal activities) to 2012 (closure of the dumpsite). The amount of waste landfilled in the area for Scenario 2 was calculated using the volume obtained through the 3D DTM created for this site through the images captured by UAV. It was used for both scenarios the biogas generation method proposed by Intergovernmental Panel on Climate Change - IPCC and the method proposed in version 3.02 of Landfill Gas Emissions Model (LandGEM) used by the United States Environmental Protection Agency - USEPA.

\subsection{Study Area}

The study area, represented in Figure 1, is located in the middle valley of Paraiba do Sul, between Serra do Mar and Serra da Mantiqueira at a latitude $\left(-22^{\circ} 23^{\prime}\right)-\left(-22^{\circ} 40^{\prime}\right)$ south and longitude ($\left.44^{\circ}\right)-\left(-44^{\circ} 12^{\prime}\right)$ west. The site is located $25 \mathrm{~km}$ from the center of Volta Redonda, Rio de Janeiro, Brazil. The beginning of irregular disposal of MSW was in 1987. In 2007 the open dump was partially remedied, becoming a controlled landfill. 


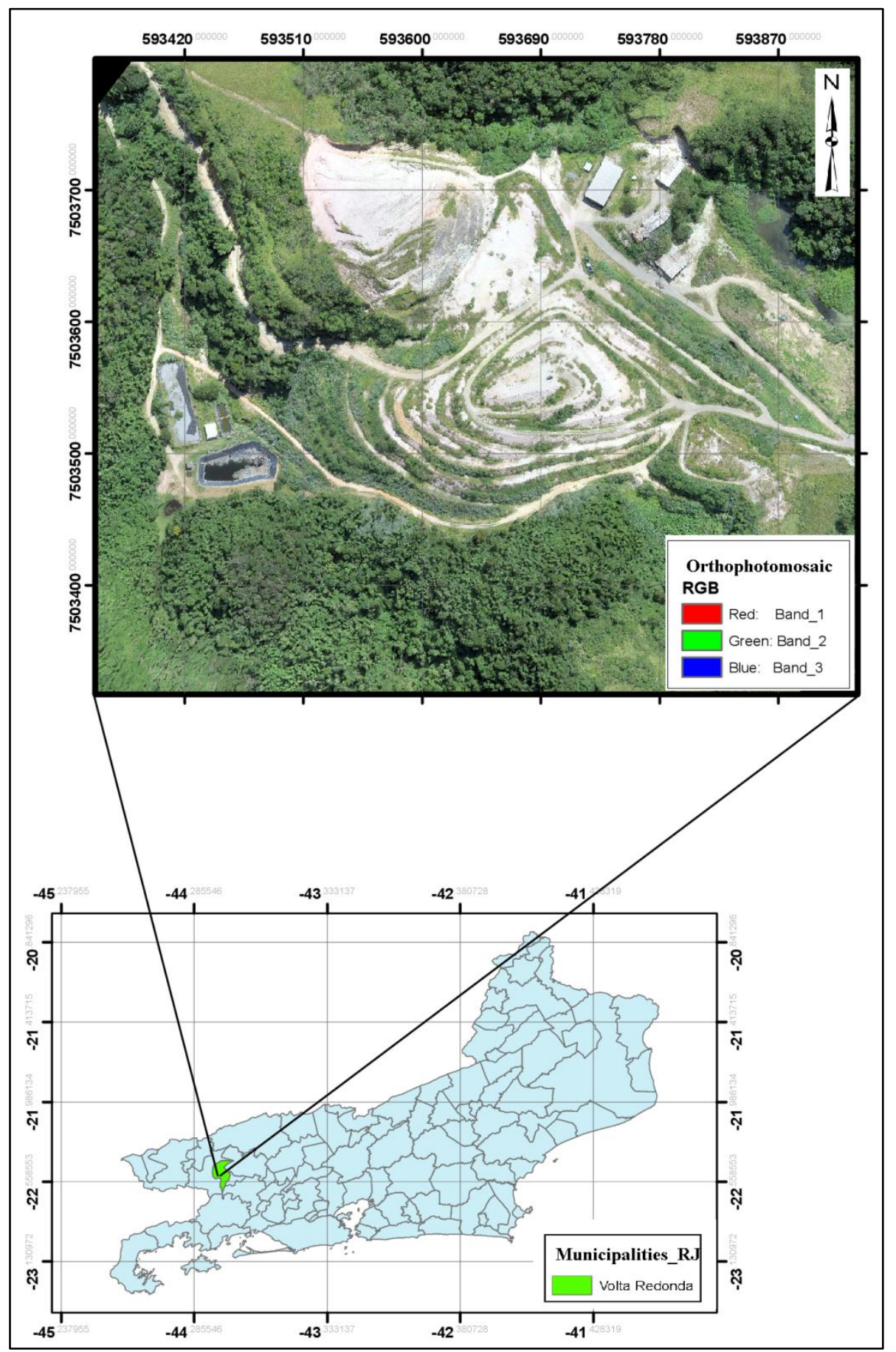

Figure 1: Location of the study area and georeferenced orthophoto mosaic.

The area is georeferenced by the Brazilian Geodetic System using Universal Transverse Mercator (UTM) projection, datum SIRGAS-2000 with the coordinates indicated in Figure 1. The orthophoto was developed by overlapping and correcting the composition of the red, green and blue spectral bands of the aerial photographs.

\subsection{Topographical Survey Planialtimetric Performed with Unmanned Aerial Vehicle}

The aerial photographs were obtained with a digital camera coupled in a remote sensing platform - UAV (provided by GEO 3 Topography Company). The digital camera characteristics are: Canon 
PowerShot S-100 12 megapixel, pixel size: $1.86161 \times 1.86161$, without pre-calibration, nominal focal length of $5.2 \mathrm{~mm}$, lens F / 2.0, maximum shutter speed of 1/13 s, $4000 \times 3000$ image size. This system uses GPS for spatial orientation, pressure sensors and telemetry for determining flying height and speed as well as the flight attitude. The UAV main characteristics are: internal flight controllers, global positioning system, open source radio telemetry, six engines, FrSky Taranis X9D control radio, redundancy system for engine and sensor failure, Lipo battery (Lithium Polymer) with 4 cells of 16,000 milliampere hour, folding propellers, carbon fiber fuselage, camera stabilization support, maximum horizontal speed of $90 \mathrm{~km} \cdot \mathrm{h}^{-1}$, vertical top speed of $14 \mathrm{~km} . \mathrm{h}^{-1}$, maximum radio control range of $1.5 \mathrm{~km}$, flight time with 40-minute Lipo battery and $3 \mathrm{~kg}$ load capacity.

The methodology used to obtain the cartographic products using the UAV was performed in three stages: (i) flight planning; (ii) execution of the flight and (iii) post-processing of the images.

The three stages were subdivided according to the following steps: 1 - indication of the area of interest with the definition of the precision to be adopted (Ground Sampling Distance - GSD of 4 $\mathrm{cm}$, that is, each pixel of the image represents $4 \mathrm{~cm}$ in the ground $\left.-16 \mathrm{~cm}^{2}\right) ; 2$ - definition of two flight plans in Mission Planner software; 3 - definition of the number of Ground Control Points GCP (GCP are used to make the relation between the coordinate system of the aerial photography and the terrain coordinate system); 4 - setting-up of field targets (GCP materialized in a black and white tarp of $0.40 \times 0.40 \mathrm{~m}$, in other words, it is an artificial mark in the field that can be identified in aerial photographs, thus providing more accurate measurements of the coordinates of the GCP for orientation of aerial photos); 5 - transfer of flight plan to UAV Vortex One; 6 - manual activation for take-off of the UAV with the camera attached, according to the established flight plans.; 7 Start of the autopilot from a predetermined height and execution of the flight plan; 8 - after end of each flight, the photos of the camera are downloaded in a portable computer to verify the process of capturing the images; 9 - georeferencing of GCP and determination of orthometric parameters of GCPs in the three axes (X, Y and Z), using the Global Navigation Satellite System (GNSS) technology, as described next: implementation of a fixed support base for the equipment - GNSS BASE, with a Hi-Target V30 L1 / L2 GNSS receiver serial number 006434, with recording interval of 1 ' and $15^{\circ}$ elevation mask. After each target (GCP) is tracking with the Hi-Target GNSS receiver V30 L1 / L2 - serial number 006435 (GNSS MOBILE equipment), using Real Time Processing (RTK) technique in which corrections are instantaneous increasing accuracy to the centimeter level; 10 - Fixed GNSS data (BASE) are downloaded and processed using Brazilian Institute of Geography and Statistics service - Positioning by Precision Point (PPP), obtaining the coordinate of the georeferenced base to DATUM SIRGAS 2000 (Geocentric Reference System for the Americas). The altitude above mean sea level is determined by the difference of the reference geoidal and ellipsoidal surface; 11 - After the coordinates of the targets has been collected with GNSS MOBILE, these are adjusted according to the new coordinates of GNSS BASE (georeferenced to DATUM SIRGAS 2000); 12 - for the correction of heights, the MAPGeo 2015 model (open source) was used in which the value of the Geoid Undulation for the GCP is calculated, converting Geoid Altitude (referenced to Geoid) in Orthometric Altitude (referenced to sea level); 13 - Agisoft PhotoScan software (multi-image 3D reconstruction technology with at least two distinct images) was used for the post-processing of data collected in the field (aerial photos and coordinates of the targets): first, the camera is calibrated based on the interchangeable image file data of the aerial photographs, after, the alignment of the photos from the points in common between the photographs and the GCP is performed automatically and finally the software generates a point 
cloud made by means of similarity measurements between the overlapping images identifying the three - dimensional coordinates $(X, Y, Z)$ of the photographed surface - image correlation.

Has been used 14 GCP to guide the aerial photographs and also as reference points to evaluate the accuracy of the 3D terrain digital model. A functional flowchart was developed to represent the logical procedure shown in Figure 2.

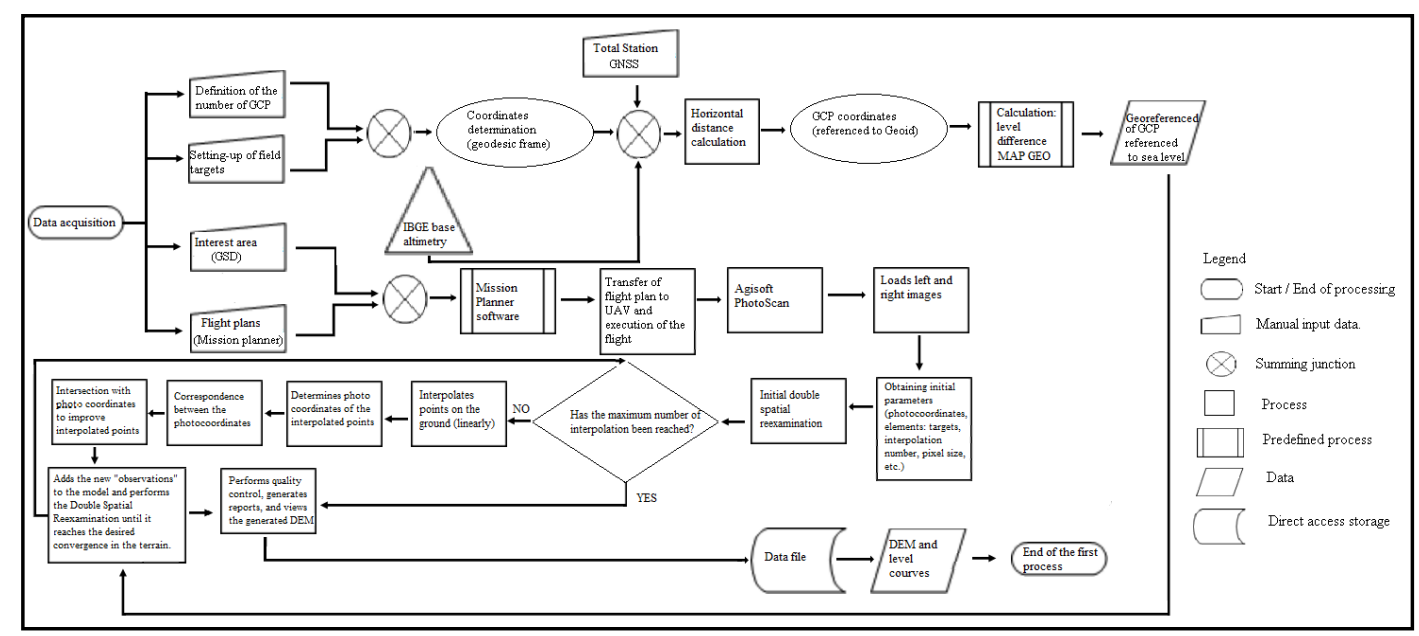

Figure 2: First stage of operational procedures

The first stage in the operational procedure performed with the aerial images obtained with the UAV and with the GPC allowed the generation of the following products: a georeferenced mosaic of images, contour lines every meter and point cloud.

\subsection{D Digital Terrain Model}

The digital photogrammetry with UAV allows representing the variable altimetry by means of 3D terrain digital model, developed based on point cloud obtained by the indirect method of remote sensing equipment. Two model representations are developed: Digital Terrain Model (DTM) and Digital Surface Model (DSM). In DSM objects on the surface are represented (e.g. buildings, vegetation) and in DTM only the relief is represented (Silva et al. 2016). Considering that the study area does not present objects on the surface the DSM represents the DTM.

A DTM was generated from the contour lines obtained by filtering the point cloud generated by the surface modeling technologies. Using the filtered point cloud obtained with the software AgisoftPhotoscan and the GCP coordinates ( $X, Y$ and $Z$ ) on the surface of the controlled landfill, a Triangular Irregular Networks (TIN) was created in ArcGIS software version 10.3.

Through the routine described below, the real surface area and volume of MSW was determined: The file in shapefile format obtained by Agisoft PhotoScan program was selected: contour lines; The GCP coordinates obtained by the GNSS were selected; The files were loaded into ArcMap for processing; The extension 3D Analyst was enabled. The 3D Digital Terrain Model was created with the selected files, in ArcMap, (Triangular Irregular Network - TIN): 3D Analyst $\rightarrow$ Create / Modify TIN $\rightarrow$ Create TIN from the features; By TIN, the volume of waste landed and the real surface area was calculated: 3D Analyst Tools $\rightarrow$ Terrain and TIN surface $\rightarrow$ Polygon Volume.

The functional flowchart in Figure 3 shows the acquisition and the treatment of the spatial data. 


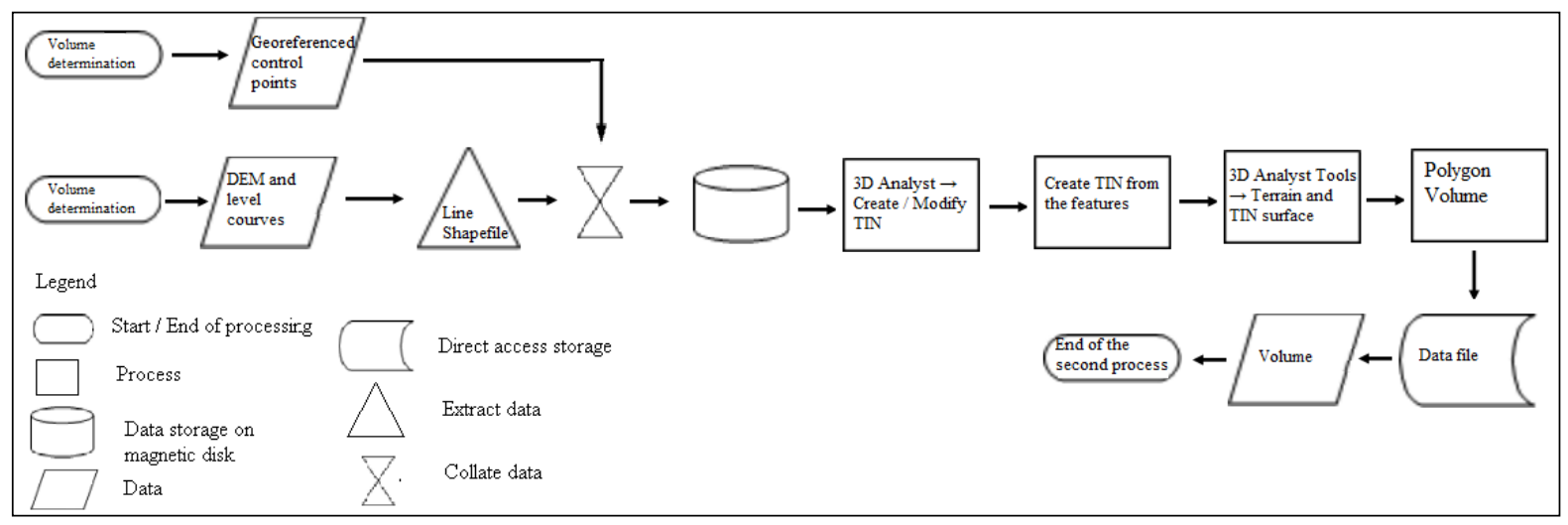

Figure 3: Second stage of operational procedures

The morphological parameters of the site (area, volume and perimeter) were obtained through software ArcGIS 10.3 (provided by Geotechnology Laboratory of the State University of Rio de Janeiro)

\subsection{Biogas Generation}

After determination of the volume of MSW was used the method of the first order decomposition proposed by IPCC (Equation 1) as well as the model used by USEPA (Equation 2) to quantify the biogas generation in the disposal area. (IPCC 1996; Santos, Van Elk and Romanel, 2015; USEPA 2005)

$Q_{\mathrm{CH}_{4}}=\sum_{x}^{t}\left(A \cdot k \cdot L_{0} \cdot M S W_{x} \cdot \mathrm{e}^{-k t_{x}}\right)$

Where: $t=$ year of inventory [year]; $x=$ years for which input data should be added [year]; $A=(1$ $\left.\mathrm{e}^{-k}\right) \cdot k^{-1}$ is a normalization factor which corrects the summation; $Q_{\mathrm{CH}_{4 i}}=$ Methane produced in the year " $i$ " [ton.year $\left.{ }^{-1}\right] ; k=$ methane generation rate constant $\left[1\right.$.year $\left.{ }^{-1}\right] ; L_{0}=$ Methane generation potential [ton $\mathrm{CH}_{4} \cdot \operatorname{ton}^{-1} \mathrm{MSW}_{\mathrm{x}}$ ]; $\mathrm{MSW}_{\mathrm{x}}=$ waste deposited in the year " $\mathrm{x}$ " [ton].

$Q_{C H_{4}}=\sum_{i=1}^{n} \sum_{j=0,1}^{1} k \cdot L_{0} \cdot\left(m_{i} \cdot 10^{-1}\right) \cdot e^{-k t_{i j}}$

Where: $Q_{\mathrm{cH} 4 \mathrm{i}}=$ Methane produced in the year " $\mathrm{i}$ " $\left[\mathrm{m}^{3} \mathrm{CH}_{4} \cdot\right.$ year $\left.{ }^{-1}\right] ; \mathrm{i}=1$ year time increment; $\mathrm{n}=$ (year of calculation) - (initial year of waste disposal); $j=0,1$ year time increment; $k$ : methane

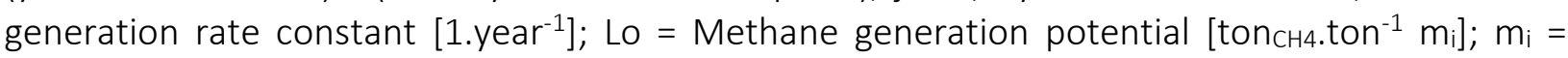
waste disposal in the year "i" [ton]; $t_{i j}=$ age of section $j$ of $m_{i}$ disposal in year $i$ [year]

The potential for methane generation $\left(L_{0}\right)$ from waste was obtained by Equation 3.

$$
L_{0}=M C F \cdot D O C \cdot D O C_{f} \cdot F \cdot\left(16 \cdot 12^{-1}\right)
$$

Where: $\mathrm{L}_{0}=$ methane generation potential $\left[\operatorname{ton}_{\mathrm{CH}_{4}} \cdot \operatorname{ton}^{-1} \mathrm{MSW}_{\mathrm{x}}\right.$ ]; MCF = methane correction factor in year $\mathrm{x}$ [fraction]; $\mathrm{DOC}=$ Degradable Organic Carbon $(\mathrm{DOC})$ in year $\mathrm{x}$ (fraction) [ton $\mathrm{C}$. ton $^{-1}$ MWS $;$ : $D_{C}=$ Fraction of DOC dissimilated; $F=$ Fraction by volume of $\mathrm{CH}_{4}$ in landfill gas; $16.12^{-1}=$ Conversion factor from $\mathrm{C}$ to $\mathrm{CH}_{4}$.

The calculation of the amount of degradable organic carbon (DOC) was performed using the regression equation developed for the southeast region of Brazil, Equation 4 (CETESB 2010). 


$$
D O C_{x S E}=-0,000710593 x+1,584468345
$$

Where: angular coefficient $=-0,000710593$ [ton C.(ton MSW.year) $)^{-1}$ ]; linear coefficient: 1,584468345 [ton C.(ton MSW.year) ${ }^{-1}$ ].

The dissimilated fraction of degradable organic carbon (DOC $)$ was calculated by Equation 5 .

$$
D O C_{f}=0,014 . T+0,28
$$

Where: $\mathrm{DOC}_{\mathrm{f}}=$ fraction of $\mathrm{DOC}$ dissimilated; $\mathrm{T}$ : temperature in the anaerobic zone $\left[{ }^{\circ} \mathrm{C}\right]$.

\subsection{Validation}

The validation of the UTM coordinates accuracy in the DTM was made through the difference between the location of the post-processed points of the orthophotos and the GCPs obtained with the GNSS technology.

With the characteristics of the flight performed it is possible to find the cartographic scale of the orthophoto by calculating GSD (Ground Sampling Distance). The GSD can be confirmed by Equation 6.

$$
G S D=\left(d \cdot h_{v}\right) \cdot f^{-1}
$$

Where: $h_{v}$ is the average height of the flight, $f$ is the focal length of the camera and $d$ is the physical size of the pixel in the sensor.

After the identification of these points, the Root Mean Square Error (RMSE) was calculated. For the calculation of the RMSE, the following equation was used (Equation 7):

$$
R M S E=\sqrt{\frac{\sum(\Delta h)^{2}}{n}}
$$

Where: $\Delta h$ is the difference between the location of the post-processed points of the orthophotos and the GCP, $n$ is the number of points on the ground.

\section{Results and Discussion}

\subsection{Topographic Survey by Unmanned Aerial Vehicle}

The planialtimetric survey, such as the contour lines, was carried out by processing 246 overlapping images obtained by the camera attached to the UAV. Figure 4 shows the location and the number of images captured by the camera at different points of the flight plan. A cloud of points automatically generated by the program Agisoft PhotoScan (dense and sparse) which provided the obtaining the contour lines and the orthophoto mosaic. From the contour lines and the GCP the 3D DTM was created - Triangular Irregular Network (TIN), shown in Figure 5.

The results of the flight performed in this study are described in Table 2 and Table 3 indicates the RMSE in the three axes ( $X, Y$ and $Z$ ) that were used for precision evaluation of the 3D DTM. 


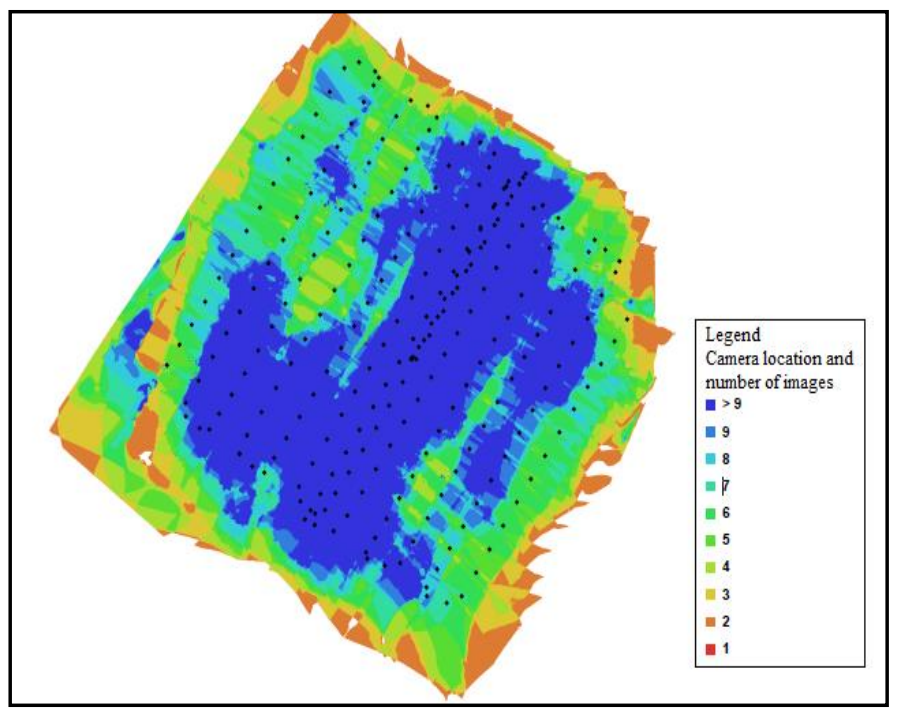

Figure 4: Camera locations and image overlap

The different colors indicate the number of images captured at the shooting times of the camera connected to the UAV. The quality of the model decreases at the edges due to the small number of images obtained. However, a large number of photos of the study area located further to the center indicated by the blue color were acquired, thus minimizing edge effects.

Table 2: Characteristics of the flight performed

\begin{tabular}{l|l}
\hline Number of images: 246 & Camera stations: 242 \\
\hline Flying altitude: $119.957 \mathrm{~m}$ & Tie-points: 434905 \\
\hline Ground resolution: $0.0370436 \mathrm{~m} / \mathrm{pix}$ & Projections: 1096930 \\
\hline Coverage area: $0.503073 \mathrm{sq} . \mathrm{km}$ & Error: 0.907785 pix \\
\hline
\end{tabular}

The mean error obtained with the photographic camera GPS was $9.5 \mathrm{~m}$ for the $\mathrm{X}$ axis, $11.77 \mathrm{~m}$ for the $Y$ axis and $10.33 \mathrm{~m}$ for the $Z$ axis. They are high-value errors that are automatically corrected with the introduction of the coordinates of the GCP, obtained with GNSS, during post-processing. The software uses the coordinates obtained with GNSS as a reference in its aero triangulation, with this it transports these coordinates to the rest of the pixels in the image thus doing the georeferencing of the images in which each pixel of the image will have its coordinate established. Still, with the GCP and through the process of analysis of pixel to pixel, the software performs the automatic identification of the homologous points, also known as Tie Points, which in this study totaled 434,905 tie-points, significantly higher in relation to a conventional survey $(5,023$ points) (Silva et al. 2016). 246 image captures were performed in 242 different positions used to generate the orthophoto.

With the data in Table 2 it is possible to find the cartographic scale of the orthophoto by calculating GSD (Ground Sampling Distance). A result of $4.3 \mathrm{~cm}$ for GSD was obtained, confirming GSD initially set at $4 \mathrm{~cm}$. Therefore the cartographic scale is $1: 400$ 
Table 3: Root Mean Squared Error.

\begin{tabular}{l|l|l|l|l|l|l}
\hline GCP & X error $(\mathrm{m})$ & Y error $(\mathrm{m})$ & Z error $(\mathrm{m})$ & Error $(\mathrm{m})$ & Projections & Error $($ pix $)$ \\
\hline PC1 & 0.095086 & 0.03366 & -0.020649 & 0.102960 & 13 & 0.865925 \\
\hline PC2 & -0.027270 & -0.044214 & -0.172140 & 0.179807 & 10 & 0.837532 \\
\hline PC3 & -0.060074 & -0.012964 & -0.007562 & 0.061920 & 5 & 0.269254 \\
\hline PC4 & 0.096080 & 0.036987 & 0.027292 & 0.106510 & 4 & 0.307263 \\
\hline PC5 & -0.163865 & -0.016133 & -0.120826 & 0.204233 & 6 & 0.460727 \\
\hline PC7 & 0.030052 & -0.015812 & -0.023063 & 0.041049 & 18 & 0.257590 \\
\hline PC8 & 0.043154 & -0.002165 & 0.074088 & 0.085767 & 14 & 0.434430 \\
\hline PC9 & -0.066381 & 0.023280 & -0.025923 & 0.074969 & 16 & 0.326107 \\
\hline PC10 & -0.023247 & -0.093424 & -0.250254 & 0.268133 & 13 & 1.910172 \\
\hline PC11 & -0.085982 & 0.008585 & 0.094457 & 0.128019 & 10 & 0.915775 \\
\hline PC12 & -0.019735 & 0.032589 & -0.236257 & 0.239310 & 9 & 1.027207 \\
\hline PC13 & 0.063005 & -0.069506 & -0.190350 & 0.212212 & 17 & 3.724849 \\
\hline PC15 & -0.009450 & 0.048250 & 0.697045 & 0.698777 & 16 & 5.557292 \\
\hline MSE & 0.019295 & 0.011074 & 0.062008 & 0.247038 & 151 & 2.329814 \\
\hline
\end{tabular}

The points PC6, PC 14, PC 16 and PC 17 were not in the coverage area, so were not listed in Table 3.

The results presented in Table 3 indicating the total accumulated error of $18.4892 \mathrm{~cm}$ and 1.2938 pixels shows that the precision of the survey. The mooring of GCP with the coordinates of overlapping images obtained with the UAV enabled the generation of contour lines and consequently the 3D Digital Terrain Model, DTM - TIN with a resolution of $29.6349 \mathrm{~cm}$. pix ${ }^{-1}$ and a density of 40,6261 points per square meter.

The orthophoto precision classification standards obtained with conventional digital photogrammetry correlate the GSD and root mean squared error in the three axes with the precision. For this research, these values were for the GSD $=0.043 \mathrm{~m}$ and for the RMSE total in the $X$ axis of $R_{M S E}=0.019295 \mathrm{~m}$, in the $Y$ axis of $R_{M S E}=0.011074 \mathrm{~m}$ and in the $Z$ axis was of $\mathrm{RMSE}_{\mathrm{z}}=0.062008 \mathrm{~m}$.

According to the Technical Specification for the Acquisition of Vector Geospatial Data and the Cartographic Accuracy Standard (Decree No. 89.817 / 84), the class obtained in this research is class A (high precision surveys) (Silva et al. 2016).

The best cartographic representation was obtained due to the lower equidistance between the contour lines, modeling with greater precision the relief. It should be noted that the knowledge of the degree of precision of the DTM generated through the RMSE is extremely important, since it indicates the precision of the final cartographic product.

Using the point cloud, contour lines were generated at each meter. Contour lines were introduced in the GIS environment - ArcGis - and the DTM was developed as shown in Figure 5. 
This DTM has a Triangular Irregular Networks (TIN) that represents a structure formed by interconnected triangles, representing better the nonhomogeneous surface and the local variations of the study area. Scanning with the UAV through the correlation of overlapping images obtained a point cloud with more than 1 million points and average density of 29.83 points $/ \mathrm{m}^{2}$.

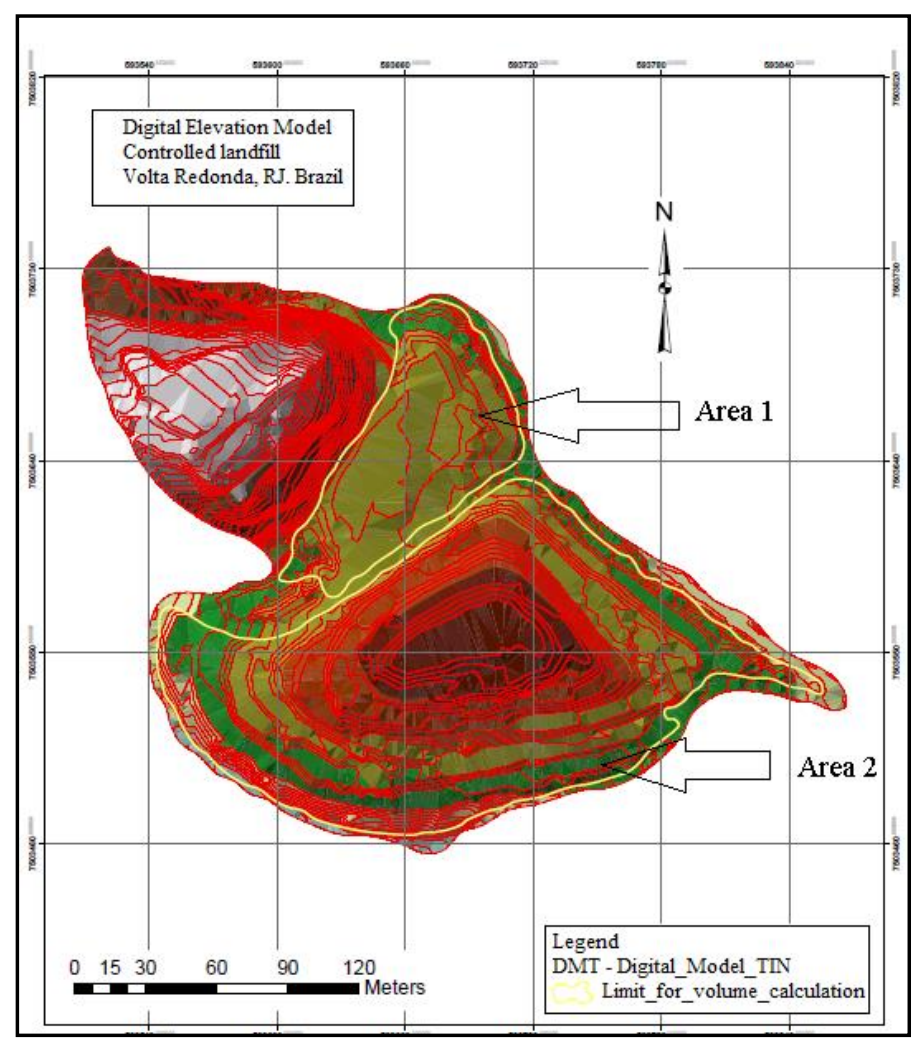

Figure 5: Triangular Irregular Network / limit for the calculation of the volume of waste landfilled and real land area.

Toz and Endorgan (2008) showed that DTM produced from contour lines has approximately two times better accuracy according to the DTMs produced by image matching. The DTM produced in this work was performed from the contour lines with one meter of equidistance. The model was developed by interpolation of elevation values ( $Z$ axis), creating triangles between one contour line and another. The model represents the space below a group of triangles of various sizes. The polygons boundaries intersect with the surface interpolation zone of the base $(Z=0)$ to estimate the volume of landed waste, identifying the common area between them. Thus the volume and surface area are estimated individually for all triangles and also for their parts that are within the intercepted polygon. The determined volume considers the real relief and not just the surface area. The morphological parameters of the controlled landfill are presented in Table 4.

Table 4: Real surface area, volume and perimeter of the controlled landfill.

\begin{tabular}{l|l|l|l}
\hline Area/Parameters & Area $\left(\mathrm{m}^{2}\right)$ & Perimeter $(\mathrm{m})$ & Volume $\left(\mathrm{m}^{3}\right)$ \\
\hline Area 1 & $7,739.73$ & 393.9 & $47,419.1$ \\
\hline Area 2 & $29,031.23$ & 789.33 & $488,336.68$ \\
\hline Total & $36,770.96$ & $1,183.23$ & $535,755.79$ \\
\hline
\end{tabular}


To estimate the volume between the surfaces, the non-linear interpolation method (natural neighbors) was used. The results presented in Table 4 are input data for quantification of the biogas flow rate.

Considering that the RMSE in the three axes is within the range established for high precision surveys, it can be stated that the generated DTM also presents the same accurate that coordinates.

According to Silva et al. (2016), aerial survey with UAV has the following characteristics in relation to traditional surveys: survey time - $98.9 \%$ lower than the GNSS survey and $98.61 \%$ lower than the LIDAR survey; equipment cost - $27 \%$ lower than the GNSS survey and $93.12 \%$ lower than the LIDAR survey and, finally, $70 \%$ more accurate than the GNSS survey and $77 \%$ more accurate than the LIDAR survey.

\subsection{Methane Generation Estimation}

The modeling was based on two scenarios, scenario 1 and scenario 2 . The input data on biogas estimation model for scenario 1 were: per capita waste generation rate and the population of Volta Redonda for the years of landfill operation (methodology used by the Brazilian government). The input data on biogas estimation model for scenario 2 were: volume of landfilled waste determined using the 3D DTM - TIN. The other parameters were kept equal for the two methods in order to show the generation difference promoted exclusively by the parameter - volume of MSW landfilled.

The waste disposal operations in the area began in 1987 and ended in 2012. It was determined for scenario 1 the number of inhabitants in Volta Redonda between the years 1987 and 2012 and per capita waste generation rate for the years of landfill operation. Through these data, it was estimated the total amount of waste deposited in the landfill every year, which provided the quantification of methane flow.

The volume of MSW landed estimated for Scenario 2 was multiplied by the specific weight of MSW landed and it was found the total mass. The total weight is divided between the years of operation of the landfill. Finally, it was subtracted from the total volume of soil cover.

Table 5 shows the evolution of the population in the city of Volta Redonda, the per capita waste generation rate and the total amount of MSW estimated for Scenario 1 and determined by 3D DTM-TIN for Scenario 2, between the years 1987- 2012 (Datasus 2016; Abrelpe 2007; Abrelpe 2008; Abrelpe 2009; Abrelpe 2010; Abrelpe 2011; Abrelpe 2012).

Per capita waste generation rate increased between the years $1987\left(0.5 \mathrm{~kg}\right.$. hab ${ }^{-1}$. day $\left.{ }^{-1}\right)$ to 2012 $\left(1.3 \mathrm{~kg}\right.$. hab ${ }^{-1}$. day $\left.{ }^{-1}\right)$. The per capita waste generation rate is used to quantify the annual solid waste generation (in tonnes) of a city that does not have measurements of this variable in the areas of final disposal. The density adopted for this model for solid waste landed with compression was $700 \mathrm{~kg} \cdot \mathrm{m}^{-3}$. This average density was obtained through a survey conducted by the Brazilian government in several landfills and used as the average parameter for the determination of the methane rate generated in the Volta Redonda landfill. The moisture content adopted, which is the amount of water presented in the waste measured as a percentage of its weight was $60 \%$ (SEDU 2001; EPE 2014), being the average humidity presented by the Brazilian government for the modeling of landfill biogas and GHG communication for UNFCC. The volume of soil covering of $19.551 \mathrm{~m}^{3}$ was subtracted from the initial volume of waste landed for scenario 2 (Rizoma 2007). 
In order to present a comparative analysis between the biogas generation in the two scenarios, it was adopted the same parameters for both, facilitating the identification of the main parameter that promotes the generation difference obtained between the two scenarios.

For Scenario 1 the percentage of MSW collected between the years 1987-2007 was 80\% increased to $100 \%$ in the following years.

Table 5: Estimated amount of MSW for scenarios 1 and 2.

\begin{tabular}{|c|c|c|c|c|c|c|}
\hline Year & $\begin{array}{l}\text { Population } \\
\text { (hab) }\end{array}$ & $\begin{array}{l}\text { Per capita } \\
\text { generation } \\
\left(\text { kg.hab }^{-1}\right. \\
\left.\text {.day }{ }^{-1}\right)\end{array}$ & $\begin{array}{l}\text { Collected } \\
\text { waste (\%) }\end{array}$ & $\begin{array}{l}\text { Scenario 1: Annual } \\
\text { generation } \\
\text { (ton.year }{ }^{-1} \text { ) }\end{array}$ & $\begin{array}{l}\text { Waste } \\
\text { volume (3D } \\
\text { model - } \\
\left.\mathrm{m}^{3}\right)\end{array}$ & $\begin{array}{l}\text { Scenario 2: } \\
\text { Annual } \\
\text { generation } \\
\text { (ton.year-1) }\end{array}$ \\
\hline 1987 & 207068 & 0,5 & 0,88 & 33122 & 19854,03 & 13897,82 \\
\hline 1988 & 210362 & 0,53 & 0,88 & 35689 & 19854,03 & 13897,82 \\
\hline 1989 & 213571 & 0,56 & 0,88 & 38331 & 19854,03 & 13897,82 \\
\hline 1990 & 216701 & 0,59 & 0,88 & 41051 & 19854,03 & 13897,82 \\
\hline 1991 & 220305 & 0,62 & 0,88 & 43872 & 19854,03 & 13897,82 \\
\hline 1992 & 222477 & 0,66 & 0,88 & 47193 & 19854,03 & 13897,82 \\
\hline 1993 & 226533 & 0,69 & 0,88 & 49857 & 19854,03 & 13897,82 \\
\hline 1994 & 228564 & 0,72 & 0,88 & 52570 & 19854,03 & 13897,82 \\
\hline 1995 & 230540 & 0,75 & 0,88 & 55336 & 19854,03 & 13897,82 \\
\hline 1996 & 232287 & 0,79 & 0,88 & 58766 & 19854,03 & 13897,82 \\
\hline 1997 & 235274 & 0,82 & 0,88 & 61778 & 19854,03 & 13897,82 \\
\hline 1998 & 237792 & 0,85 & 0,88 & 64710 & 19854,03 & 13897,82 \\
\hline 1999 & 240316 & 0,88 & 0,88 & 67698 & 19854,03 & 13897,82 \\
\hline 2000 & 242063 & 0,91 & 0,88 & 70753 & 19854,03 & 13897,82 \\
\hline 2001 & 244715 & 0,95 & 0,88 & 74328 & 19854,03 & 13897,82 \\
\hline 2002 & 246642 & 0,98 & 0,88 & 77159 & 19854,03 & 13897,82 \\
\hline 2003 & 248765 & 1,01 & 0,88 & 80022 & 19854,03 & 13897,82 \\
\hline 2004 & 250884 & 1,04 & 0,88 & 82918 & 19854,03 & 13897,82 \\
\hline 2005 & 255697 & 1,08 & 0,88 & 86649 & 19854,03 & 13897,82 \\
\hline 2006 & 258145 & 1,11 & 0,88 & 89618 & 19854,03 & 13897,82 \\
\hline 2007 & 260570 & 1,14 & 1 & 106377 & 19854,03 & 13897,82 \\
\hline 2008 & 259811 & 1,17 & 1 & 110952 & 19854,03 & 13897,82 \\
\hline 2009 & 261404 & 1,21 & 1 & 115449 & 19854,03 & 13897,82 \\
\hline 2010 & 257803 & 1,24 & 1 & 116682 & 19854,03 & 13897,82 \\
\hline
\end{tabular}




\begin{tabular}{l|l|l|l|l|l|l}
\hline 2011 & 258834 & 1,27 & 1 & 120065 & 19854,03 & 13897,82 \\
\hline 2012 & 259870 & 1,3 & 1 & 123455 & 19854,03 & 13897,82 \\
\hline
\end{tabular}

The total annual of MSW generated in scenario 1 was obtained by multiplying the number of inhabitants by the per capita waste generation rate and collection rate of MSW. After 2007, the MSW collection rate was $100 \%$.

The total amount of MSW landed calculated for scenario 2 was divided by the years of landfill operation, thereby obtaining a constant value for each year. The values in cubic meters were multiplied by the density of the compacted waste, obtaining the values in tons.

The estimated quantities of waste for the two scenarios shown in Table 5 were used as parameters in models for methane flow rate quantification. To calculate the methane flow rate the following parameters are necessary: MCF; DOC; DOCf; F; A; k, Lo.

The adopted methane correction factor (MCF) was suggested by the IPCC according to landfill characteristics (0.4: open dump; 0.6: controlled landfill). Considering that the area was rehabilitated in 2012 the MCF increased from 0.4 to 0.6 in the following years thus modifying the rate produced. It was used linear regression equation for calculation of DOC. The characteristics of the residues (percentage of food, paper, glass and others) are represented by this equation in both scenarios. The fraction of DOCf dissimilated was 0.77 , for the temperature of $350 \mathrm{C}$.

The value of 0.5 was adopted for the methane fraction present in biogas (F), as the IPCC recommendation. The density of methane used was 0.0007168 ton. $\mathrm{m}^{-3}$.

The normalization factor $(A)$ depends on the value of the constant decay of methane $(k)$. This constant decay $(\mathrm{k})$ used took into account the precipitation and the values adopted was provided by the World Bank. The adopted value was 0.06 . The precipitation data were obtained at Volta Redonda Climatological Station (Code: 2244041), operated by the public company Natural Resources Research Company (Geological Survey of Brazil - CPRM).

The methane generation potential (Lo) was calculated using the degradable organic carbon, For LandGEM model the average of $L_{0}=56 \mathrm{~m}^{3} \cdot$ ton $^{-1}$ was used.

Table 6 presents a summary of results obtained for calibration model parameters. Table 7 presents the estimates of methane generation for Scenario 1 and 2, using IPCC methodology. Figure 6 shows the variation of methane generation over time for the calculations presented in Table 6 . Table 8 presents the estimates of methane generation for scenario 1 and 2, using USEPA methodology and Figure 7 shows the variation of methane generation within the time for the calculations presented in Table 8. 
Table 6: Parameters used in the model calibration for scenarios 1 and 2.

\begin{tabular}{|c|c|c|c|c|c|c|c|c|c|}
\hline Year & $F$ & $K$ & $\mathrm{DOC}_{\mathrm{f}}$ & MFC & $\begin{array}{l}\text { Conversion } \\
\text { factor }\end{array}$ & DOC & $\begin{array}{l}\text { Precipitation } \\
(\mathrm{mm})\end{array}$ & $A$ & $L_{0}$ \\
\hline 1987 & 0 & 0,060 & 0,77 & 0,4 & 1,33 & 0,1725 & 1375,4 & 0,970 & 0 \\
\hline 1988 & 0,5 & 0,060 & 0,77 & 0,4 & 1,33 & 0,1718 & 1811,4 & 0,970 & 49,09 \\
\hline 1989 & 0,5 & 0,060 & 0,77 & 0,4 & 1,33 & 0,171 & 1521,9 & 0,970 & 48,86 \\
\hline 1990 & 0,5 & 0,060 & 0,77 & 0,4 & 1,33 & 0,17 & 1218,8 & 0,970 & 48,58 \\
\hline 1991 & 0,5 & 0,060 & 0,77 & 0,4 & 1,33 & 0,1696 & 1482,2 & 0,970 & 48,46 \\
\hline 1992 & 0,5 & 0,060 & 0,77 & 0,4 & 1,33 & 0,1689 & 1329,6 & 0,970 & 48,26 \\
\hline 1993 & 0,5 & 0,060 & 0,77 & 0,4 & 1,33 & 0,1682 & 1257 & 0,970 & 48,06 \\
\hline 1994 & 0,5 & 0,060 & 0,77 & 0,4 & 1,33 & 0,1675 & 1401,2 & 0,970 & 47,86 \\
\hline 1995 & 0,5 & 0,060 & 0,77 & 0,4 & 1,33 & 0,1668 & 1571,4 & 0,970 & 47,66 \\
\hline 1996 & 0,5 & 0,060 & 0,77 & 0,4 & 1,33 & 0,1661 & 1973,8 & 0,970 & 47,46 \\
\hline 1997 & 0,5 & 0,060 & 0,77 & 0,4 & 1,33 & 0,1654 & 1421,8 & 0,970 & 47,26 \\
\hline 1998 & 0,5 & 0,060 & 0,77 & 0,4 & 1,33 & 0,1647 & 1337,6 & 0,970 & 47,06 \\
\hline 1999 & 0,5 & 0,060 & 0,77 & 0,4 & 1,33 & 0,1639 & 1261,3 & 0,970 & 46,83 \\
\hline 2000 & 0,5 & 0,060 & 0,77 & 0,4 & 1,33 & 0,1632 & 1439,7 & 0,970 & 46,63 \\
\hline 2001 & 0,5 & 0,060 & 0,77 & 0,4 & 1,33 & 0,1625 & 1178,6 & 0,970 & 46,43 \\
\hline 2002 & 0,5 & 0,060 & 0,77 & 0,4 & 1,33 & 0,1618 & 1342,5 & 0,970 & 46,23 \\
\hline 2003 & 0,5 & 0,060 & 0,77 & 0,4 & 1,33 & 0,1611 & 1455,2 & 0,970 & 46,03 \\
\hline 2004 & 0,5 & 0,060 & 0,77 & 0,4 & 1,33 & 0,16044 & 1602,1 & 0,970 & 45,84 \\
\hline 2005 & 0,5 & 0,060 & 0,77 & 0,4 & 1,33 & 0,1597 & 1351,4 & 0,970 & 45,63 \\
\hline 2006 & 0,5 & 0,060 & 0,77 & 0,4 & 1,33 & 0,159 & 1251,3 & 0,970 & 45,43 \\
\hline 2007 & 0,5 & 0,060 & 0,77 & 0,6 & 1,33 & 0,1583 & 906,2 & 0,970 & 67,85 \\
\hline 2008 & 0,5 & 0,060 & 0,77 & 0,6 & 1,33 & 0,1575 & 1486,1 & 0,970 & 67,51 \\
\hline 2009 & 0,5 & 0,060 & 0,77 & 0,6 & 1,33 & 0,1568 & 2043,1 & 0,970 & 67,21 \\
\hline 2010 & 0,5 & 0,060 & 0,77 & 0,6 & 1,33 & 0,1561 & 1539,6 & 0,970 & 66,91 \\
\hline 2011 & 0,5 & 0,060 & 0,77 & 0,6 & 1,33 & 0,1554 & 852,9 & 0,970 & 66,61 \\
\hline 2012 & 0,5 & 0,060 & 0,77 & 0,6 & 1,33 & 0,1547 & 1441,4 & 0,970 & 66,31 \\
\hline
\end{tabular}

The parameters indicated in Table 6 were used as input data for the simulation to quantification of methane generation to Scenarios 1 and 2. The potential methane generation $\left(L_{0}\right)$ indicated in the last column is dependent on the parameters: MCF (in 2007 the area was recovered and went from open dump to controlled landfill, consequently changing the adopted parameter from 0.4 to 0.6); DOC; $\mathrm{DOC}_{f}$ (temperature of $\left.35^{\circ} \mathrm{C}\right)$; F (IPCC recommendation). 
Table 7: Methane generation for Scenario 1 and 2 (IPCC).

\begin{tabular}{|c|c|c|}
\hline Year & IPCC, scenario $1\left(\mathrm{~m}^{3}\right)$ & IPCC, scenario $2\left(\mathrm{~m}^{3}\right)$ \\
\hline 1987 & 0 & 0 \\
\hline 1988 & 9608538 & 3741706 \\
\hline 1989 & 9673326 & 3507296 \\
\hline 1990 & 9700538 & 3284118 \\
\hline 1991 & 97393 & 3085226 \\
\hline 1992 & 9825714 & 2893565 \\
\hline 1993 & 9735347 & 2713763 \\
\hline 1994 & 9627079 & 2545091 \\
\hline 1995 & 9503597 & 238686 \\
\hline 1996 & 9465039 & 2238427 \\
\hline 1997 & 933122 & 2099188 \\
\hline 1998 & 916593 & 1968574 \\
\hline 1999 & 8986602 & 1844873 \\
\hline 2000 & 8807408 & 1730015 \\
\hline 2001 & 8676235 & 1622279 \\
\hline 2002 & 8445649 & 1521224 \\
\hline 2003 & 8213254 & 1426437 \\
\hline 2004 & 7981796 & 1337822 \\
\hline 2005 & 7819222 & 1254142 \\
\hline 2006 & 7582804 & 1175929 \\
\hline 2007 & 1265994 & 1653982 \\
\hline 2008 & 1237314 & 1594856 \\
\hline 2009 & 1207099 & 1453113 \\
\hline 2010 & 1143816 & 1362382 \\
\hline 2011 & 1103467 & 127729 \\
\hline 2012 & 1063735 & 1197489 \\
\hline
\end{tabular}

Figure 6 shows the variation in the methane generation between 1987 and 2012 for both scenarios. 


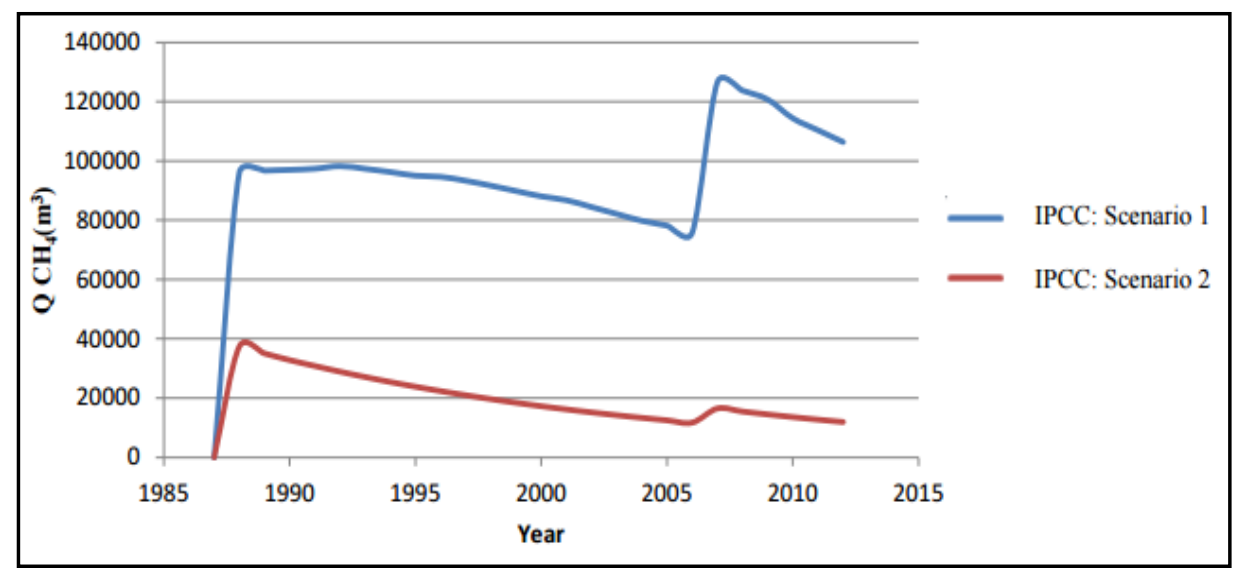

Figure 6: Variation of methane generation within time for Scenario 1 and 2 (IPCC)

The estimations presented in Table 7 and variation in time of methane flow rate shown in Figure 6 indicates a decrease in the methane generation for both scenarios between 1987 and 2006. The largest amounts generation observed after 2007 are due to interventions in landfill that changed the characteristics of the area, thereby modifying some input parameters in this simulation (i.e. MCF). It can be observed that there is a difference of one decimal place for emissions in 2007 between the two scenarios $\left(0,1 \cdot 10^{6} \mathrm{~m}^{3}\right)$.

Mebarki and collaborators (2015) conducted a modeling similar to this study using as input data the annual generation rate of waste (constant values for each year - total amount of waste generated of $64,107 \mathrm{~kg}$ ) between the years $2006-2013$, obtaining the maximum of methane generation the value of $12,106 \mathrm{~m}^{3}$ for the peak year. Aguilar-Virgin and collaborators (2014) estimating the quantity of biogas generated using parameters determined in the laboratory in accordance with the characteristics of the waste landfilled (i.e. DOC). The results indicated that the average potential methane generation was $69 \mathrm{~m}^{3}$. ton-1. These studies showed that the methane flow and the parameters used for the simulation are within the observed values, however, the appearance of the curve and the years to occur the peak flows are not in agreement with the literature which indicates the need to use a different model, in this case, the LandGEM model. 
Table 8: Methane generation for scenario 1 and 2 (LandGEM).

\begin{tabular}{|c|c|c|c|c|c|c|c|c|}
\hline Year & $\begin{array}{l}\text { LandGEM } \\
\text { (Scenario 1: } \\
\mathrm{m}^{3} \text { ) }\end{array}$ & $\begin{array}{l}\text { LandGEM } \\
\text { (Scenario } \\
\left.2: \mathrm{m}^{3}\right)\end{array}$ & Year & $\begin{array}{l}\text { LandGEM } \\
\text { (Scenario } \\
1: \mathrm{m}^{3} \text { ) }\end{array}$ & $\begin{array}{l}\text { LandGEM } \\
\text { (Scenario } \\
2: \mathrm{m}^{3} \text { ) }\end{array}$ & Year & $\begin{array}{l}\text { LandGEM } \\
\text { (Scenario } \\
1: \mathrm{m}^{3} \text { ) }\end{array}$ & $\begin{array}{l}\text { LandGEM } \\
\text { (Scenario } \\
2: \mathrm{m}^{3} \text { ) }\end{array}$ \\
\hline 1987 & 0 & 0 & 2016 & 3162000 & 485000 & 2045 & 555600 & 85130 \\
\hline 1988 & 108300 & 45460 & 2017 & 2981000 & 456700 & 2046 & 523200 & 80170 \\
\hline 1989 & 218800 & 88270 & 2018 & 2807000 & 430100 & 2047 & 492800 & 75500 \\
\hline 1990 & 331400 & 128600 & 2019 & 2644000 & 405100 & 2048 & 464100 & 71100 \\
\hline 1991 & 446400 & 166600 & 2020 & 2490000 & 381500 & 2049 & 437000 & 66960 \\
\hline 1992 & 563900 & 236000 & 2021 & 2345000 & 359300 & 2050 & 411600 & 63060 \\
\hline 1993 & 685400 & 267700 & 2022 & 2208000 & 338400 & 2051 & 387600 & 59390 \\
\hline 1994 & 808600 & 297600 & 2023 & 2080000 & 318700 & 2052 & 365100 & 55930 \\
\hline 1995 & 933500 & 325700 & 2024 & 1959000 & 300100 & 2053 & 343800 & 52670 \\
\hline 1996 & 1060000 & 352200 & 2025 & 1845000 & 286200 & 2054 & 323800 & 49610 \\
\hline 1997 & 1191000 & 377100 & 2026 & 1737000 & 266200 & 2055 & 304900 & 46720 \\
\hline 1998 & 1323000 & 400600 & 2027 & 1636000 & 250700 & 2056 & 287200 & 44000 \\
\hline 1999 & 1458000 & 422800 & 2028 & 1541000 & 236100 & 2057 & 270400 & 41440 \\
\hline 2000 & 1594000 & 443600 & 2029 & 1451000 & 222300 & 2058 & 254700 & 39020 \\
\hline 2001 & 1733000 & 463200 & 2030 & 1367000 & 209400 & 2059 & 239900 & 36750 \\
\hline 2002 & 1875000 & 481700 & 2031 & 1287000 & 197200 & 2060 & 225900 & 34610 \\
\hline 2003 & 2018000 & 499100 & 2032 & 1212000 & 185700 & 2061 & 212700 & 32590 \\
\hline 2004 & 2163000 & 515500 & 2033 & 1141000 & 174900 & 2062 & 200300 & 30700 \\
\hline 2005 & 2308000 & 530900 & 2034 & 1075000 & 164700 & 2063 & 188700 & 28910 \\
\hline 2006 & 2457000 & 545500 & 2035 & 1012000 & 155100 & 2064 & 177700 & 27220 \\
\hline 2007 & 2607000 & 559200 & 2036 & 953400 & 146100 & 2065 & 167300 & 25640 \\
\hline 2008 & 2803000 & 572100 & 2037 & 897900 & 137600 & 2066 & 157600 & 24150 \\
\hline 2009 & 3003000 & 584200 & 2038 & 845600 & 129600 & 2067 & 148400 & 22740 \\
\hline 2010 & 3206000 & 595600 & 2039 & 796400 & 122000 & 2068 & 139800 & 21420 \\
\hline 2011 & 3401000 & 606400 & 2040 & 750000 & 114900 & 2069 & 131600 & 20170 \\
\hline 2012 & 3595000 & 616500 & 2041 & 706300 & 108200 & 2070 & 124000 & 18990 \\
\hline 2013 & 3790000 & 580600 & 2042 & 665200 & 101900 & 2071 & 116800 & 17890 \\
\hline 2014 & 3569000 & 546800 & 2043 & 626400 & 95980 & 2072 & 110000 & 16850 \\
\hline 2015 & 3361000 & 515000 & 2044 & 590000 & 90390 & 2073 & 103500 & 15870 \\
\hline
\end{tabular}




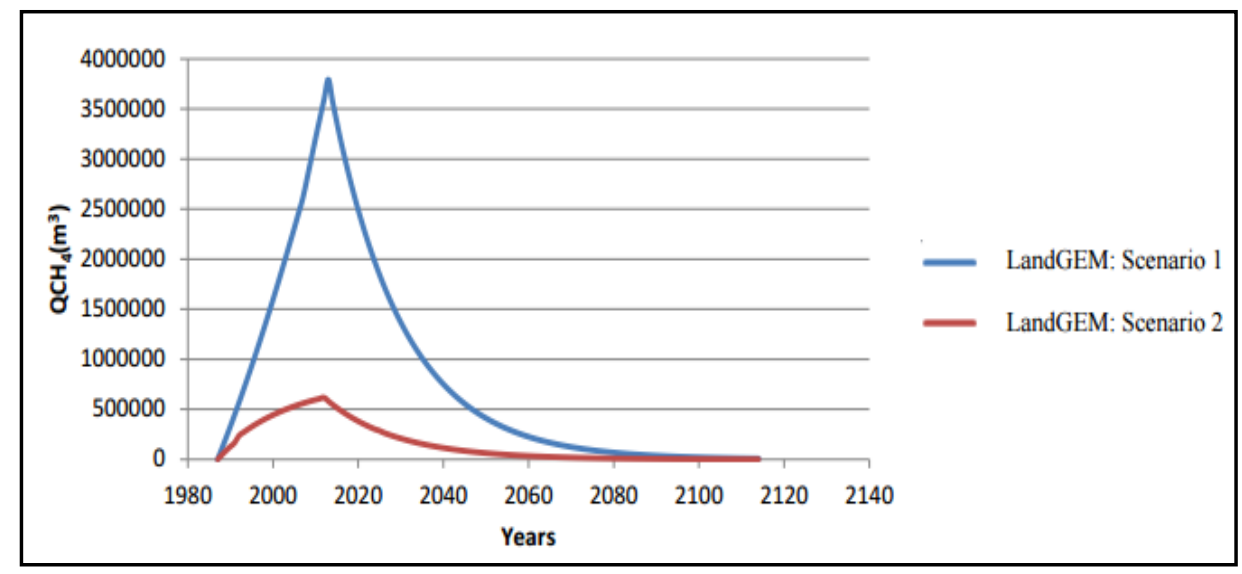

Figure 7: Variation of methane generation for Scenario 1 and 2 (LandGEM).

Through the data presented in Table 8 it is evident that there is a difference of one decimal place for emissions in both scenarios. The maximum methane flow rate for Scenario 2 was in 2012 and for Scenario 1 was in 2013. The difference between the maximum flow rate in both scenarios for the year 2012 was $0.29785 .10^{7} \mathrm{~m}^{3}$ and for the year 2013 was $0.32094 .10^{7} \mathrm{~m}^{3}$. The analysis shows that estimates of Scenario 1 methane generation are far superior to the Scenario 2 . This difference can be explained by the estimated amount of waste generated by the population of Volta Redonda through per capita waste generation rate. This estimate is usually overestimated leading to higher rates of methane generation. Figure 7 shows that for both scenarios methane generation falls dramatically after 2012 when operations at the site are closed. When using the 3D DTM - TIN to obtain the volume of waste landfilled through the geoprocessing of images taken with the UAV there is no question more precisely estimates methane generation flow rate $\left(R_{M S S}=0.019295\right.$ $\mathrm{m} ; \mathrm{RMSE}_{\mathrm{y}}=0.011074 \mathrm{~m}$ and $\mathrm{RMSE}_{z}=0.062008 \mathrm{~m}$ ). The huge difference between the methane flows for the two scenarios (Figure 7) is due to the parameter - volume of MSW landfilled. This statement can be made since all other parameters were kept constant for both models. Considering the modeling performed it can be stated that the values obtained for Scenario 1 are overestimated in relation to the values obtained through the spatial analysis.

Sil and collaborators (2014) have indicated that several models are available for estimating the emission of biogas in landfills and the LandGEM model is widely used in tropical environmental however due to inaccuracy in input data the results are often criticized and adjustments are made to improve estimates. To fill this gap both regional data and field data were used in this research thus minimizing generation uncertainties.

Chiemchaisri and Visvanathan (2008) conducted a study on biogas estimates in landfills and dumps in Thailand (tropical climate) using the method proposed by the IPCC model LandGEM model and determination of flow in a closed chamber. The results showed that the potential methane emissions using the methodology IPCC was higher than the results obtained with the LandGEM model and the estimates of the model are similar to the estimates obtained with the flow chamber thus indicating that the LandGEM model shows a good approximation of reality.

Zairi and collaborators (2014) conducted a study to quantify the generation of biogas and landfill leachates in Tunisia. They recognized that the composition of MSW in Tunisia is representative when compared to cities in developing countries. The amount of waste used in this study to determine the methane generation was estimated using per capita waste generation rate. Using model LandGEM they identified the year of peak production of methane generation as a year after of the closure of the landfill with a value of $1,765 \cdot 10^{7} \mathrm{~m}^{3} \cdot y e a r^{-1}$. Chakraborty and collaborators 
(2013) estimated the generation of methane using LandGEM model and some input parameters proposed by IPCC and others obtained experimentally for three landfills in India. The amount of waste landed was estimated. They identify the potential methane generation (LO) for waste to be 7977 and $82 \mathrm{~m}^{3}$.ton ${ }^{-1}$ for the three landfills. The constant value of methane generation $(\mathrm{k})$ used was 0.09 per year.

These surveys showed that the methane flow rate and the parameters used in the simulation are within the range observed in this study. Many studies have used methane generation input parameter in specific models estimates of the amount of waste landfilled. The estimate of the amount of waste takes into account the population growth and the per capita waste generation rate which leads to overestimation of this parameter thus leading to overestimation of methane generation.

When comparing the methane generation in both scenarios and the two different methodologies it is to be noted that the use of the real area and the volume of MSW landfilled determined by the DTM for modeling were more reliable compared to the methodology used by the Brazilian government that takes into account the estimates of waste generated by per capita waste generation rate. This affirmation can be confirmed due to Root Square Error in the process of determining the orthometric coordinates of the study area indicating errors in the centimeters thus giving the model a high precision.

Despite the LandGEM methodology is considered more effective to quantify methane generation the comparison method to be evaluated is the method of first-order decomposition proposed by the IPCC and used by the Brazilian government simply because the reporting of the greenhouse gases to the UNFCCC are performed upon the calculations of this model.

\section{Conclusions}

The planialtimetric survey conducted with UAV was agile and with few resources for this purpose. The obtained precision was possible due to the implementation of GCP that allowed the correction of the coordinates obtained from the GPS of the photographic camera engaged in UAV. RMSE in centimeters (RMSEX $=0.019295 \mathrm{~m}$; RMSEy $=0.011074 \mathrm{~m}$ and $\mathrm{RMSEz}=0.062008 \mathrm{~m}$ ) indicate the accuracy of the 3D DTM showing a resolution of 0.296349 m.pix ${ }^{-1}$ and a density of 40.6261 points per square meter.

When comparing the estimates waste generated (Scenario1) and estimates of landfilled waste (Scenario 2) there was a huge difference between them. This is mainly because, in Scenario 1 the estimates take into account the per capita generation rate of MSW which leads to inaccuracies in modeling. As in Scenario 2 the data determined by the 3D DTM (volume of MSW landfilled) represent more the reality because of georeferenced images with errors in centimeters.

The potential for methane generation $\left(L_{0}\right)$ using the linear regression equation for the degradable organic carbon calculation for the Southeast Region of Brazil can be used quite accurately as compared with other surveys and respecting the proportions (climate socio-economic factors).

Due to the uncertainties of methane generation in the model adopted by Brazilian government it is recommended to use the 3D DTM especially in areas that have no historical records of operation or in abandoned areas to quantify the volume of MSW landfilled for further calculation of the methane flow. The data provided by this research should be incorporated into the National Greenhouse and Climate Change Gases Inventory as fugitive emissions. 
Finally methane in Volta Redonda's landfill will be generated by the year 2115 for scenario 2 with the peak year 2012 with an amount of $616500 \mathrm{~m}^{3}$ when used LandGEM model.

\section{ACKNOWLEDGEMENT}

Assistance provided by GEO3 Topography with the collection of the data was greatly appreciated.

\section{REFERENCES}

Associação Brasileira de Normas Técnicas (ABNT) NBR 8419. 1992. Apresentação de projetos de aterros de resíduos sólidos urbanos. Rio de Janeiro: ABNT.

Associação Brasileira de Normas Técnicas (ABNT) NBR 8849. 1985. Apresentação de projetos de aterros controlados de resíduos sólidos urbanos. Rio de Janeiro: ABNT.

Associação Brasileira de Empresas de Limpeza Pública e Resíduos especiais (ABRELPE). 2007. Panorama dos resíduos sólidos no Brasil 2007. São Paulo: Abrelpe. Available at: <http://www.abrelpe.org.br/Panorama/panorama2007.pdf> [Accessed 22 February 2016].

Associação Brasileira de Empresas de Limpeza Pública e Resíduos especiais (ABRELPE). 2008. Panorama dos resíduos sólidos no Brasil 2008. São Paulo: Abrelpe. Available at: <http://www.globalgarbage.org/Panorama2008.pdf> [Accessed 22 February 2016].

Associação Brasileira de Empresas de Limpeza Pública e Resíduos especiais (ABRELPE). 2009. Panorama dos resíduos sólidos no Brasil 2009. São Paulo: Abrelpe. Available at: <http://www.wtert.com.br/home2010/arquivo/noticias_eventos/Panorama2009.pdf> [Accessed 22 February 2016].

Associação Brasileira de Empresas de Limpeza Pública e Resíduos especiais (ABRELPE). 2010. Panorama dos resíduos sólidos no Brasil 2010. São Paulo: Abrelpe. Available at: <http://www.abrelpe.org.br/Panorama/panorama2010.pdf> [Accessed 22 February 2016].

Associação Brasileira de Empresas de Limpeza Pública e Resíduos especiais (ABRELPE). 2011. Panorama dos resíduos sólidos no Brasil 2011. São Paulo: Abrelpe. Available at: <http://www.abrelpe.org.br/Panorama/panorama2011.pdf> [Accessed 22 February 2016].

Associação Brasileira de Empresas de Limpeza Pública e Resíduos especiais (ABRELPE). 2012. Panorama dos resíduos sólidos no Brasil 2012. São Paulo: Abrelpe. Available at: <http://www.abrelpe.org.br/Panorama/panorama2012.pdf> [Accessed 22 February 2016].

Associação Brasileira de Empresas de Limpeza Pública e Resíduos especiais (ABRELPE). 2015. Panorama dos resíduos sólidos no Brasil 2015. São Paulo: Abrelpe. Available at: < http://www.abrelpe.org.br/Panorama/panorama2015.pdf> [Accessed 22 February 2017].

Associação Brasileira de Empresas de Limpeza Pública e Resíduos especiais (ABRELPE). 2016. Panorama dos resíduos sólidos no Brasil 2016. São Paulo: Abrelpe. Available at: < http://www.abrelpe.org.br/panorama_apresentacao.cfm> [Accessed 22 February 2017]. 
Aguilar-Virgin, Q. Gonzalez, P. T. and Benítez, S. O. 2014. Analysis of the feasibility of the recovery of landfill gas: a case study of Mexico. Journal of Cleaner Production, 79, pp. 53-60.

Atta, M. and Yaacob, W. Z. W. 2015. The potential impact of leachate-contaminated groundwater of an ex-landfill site at Taman Beringin Kuala Lumpur. Environmental Earth Sciences, 73, pp. 39133923.

Barros, R. M. Filho, G. L. T. and Silva, T. R. 2014. The electric energy potential of landfill biogas in Brazil. Energy Policy, 65, pp. 150-164.

BRASIL, 2010. Lei no 12305 de 02 de agosto de 2010 que institui a Política Nacional de Resíduos Sólidos e altera a Lei no 9605 de 12 de fevereiro de 1998. Available at: <http://www4.planalto.gov.br/Legislacao> [Accessed 22 January 2016].

Biotto, G. et al. 2009. Multi-criteria and multi-factor spatial analysis for the probability assessment of the existence of illegal landfills. International Journal of Geographical Information, 23 (10), pp. 1233-1244.

Calabrò, P. S. Orsi, S. Gentili, E. and Carlo, M. 2011. Modelling of biogas extraction at an Italian landfill accepting mechanically and biologically treated municipal solid waste. Waste Management \& Research, 29 (12), pp. $1277-1285$.

Camba, A. et al. 2014. Modeling the leachate flow and aggregated emissions from municipal waste landfills under life cycle thinking in the Oceanic region of the Iberian Peninsula. Journal of Cleaner Production, 67, pp. 98 - 106.

Companhia Ambiental do Estado de São Paulo (CETESB). 2011. Inventário Estadual de resíduos sólidos domiciliares. São Paulo: CETESB.

Cortázar, A. L. G. and Monzón, I. T. 2007. MODUELO 2: A new version of an integrated simulation model for municipal solid waste landfills. Environmental Modelling \& Software, 22, pp. $59-72$.

Chakraborty, M. et al. 2013. Assessment of energy generation potentials of MSW in Delhi under different technological options. Energy Conversion and Management, 75, pp. 249-255.

Chen, Y. Knappe, D.R. and Barlaz, M.A. 2004. Effect of Cellulose/Hemicellulose and Lignin on the Bioavailability of Toluene Sorbed to Waste Paper. Environmental. Science \& Technology, 38 (13), pp. 3731-3736.

Chiemchaisri, C. and Visvanathan, C. 2008. Greenhouse Gas Emission Potential of the Municipal Solid Waste Disposal Sites in Thailand. Journal of the Air \& Waste Management Association, 58, pp. 629-635.

DATASUS, 2016. Informações de saúde: População residente por município. Cidade: 330630 Volta Redonda. Avalilable at : <http://tabnet.datasus.gov.br/cgi/tabcgi.exe?ibge/cnv/poprj.def> [Accessed 15 March 2016].

Debiasi, P. and Mitishita, E. A. 2013. The influence of aerial calibration of low cost digital camera integrated with LIDAR system in the aero triangulation process. Boletim de Ciências Geodésicas, 19 (4), pp. $687-710$.

Di Bella, G. et al. 2012. Modeling of perched leachate zone formation in municipal solid waste landfills. Waste Management, 32 (3), pp. 456-462. 
Ejaz, N. and Janjua, N. S. 2012. Solid Waste Management Issues in Small Towns of Developing World: A Case Study of Taxila City. International Journal of Environmental Science and Development, 3 (2), pp. 167-171.

El-Fadel, M. et al. 2002. Temporal variation of leachate quality from pre-sorted and baled municipal solid waste with high organic and moisture content. Waste Management, 22 (3), pp. 269-282.

Emberton, J. R. and Parker, A. 1987. The problems associated with building on landfill sites. Waste Management \& Research, 5(4), pp. 473-482.

Empresa de Pesquisa Energética (EPE). 2014. Inventário de Energia de Resíduos Sólidos Urbanos. Nota técnica DEA 18/14. Rio de Janeiro: EPE.

Feng, S. J. et al. 2015. Modeling of leachate recirculation using vertical wells in bioreactor landfills. Environmental Science and Pollution Research, 22, pp. 9067-9079.

Graça, N. L. S. S.; Mitishita, E. A. and Gonçalves, J. E. 2017. Use of UAV platform as an autonomous tool for estimating expansion on invaded agricultural land. Boletim de Ciências Geodésicas, 23 (3), pp. 509-519.

Intergovernmental Panel on Climate Change (IPCC). 1996. Revised 1996 IPCC Guidelines for National Greenhouse Gas Inventories: Reference Manual. Available at: < http://www.ipccnggip.iges.or.jp/public/gl/invs1.html> [Accessed 15 March 2016].

Kontos, T. D. et al. 2005. MSW landfills with a spatial multiple criteria analysis methodology. Waste Management, 25, pp. 818-832.

Manna, L. Zanetti, M.C. and Genon, G. 1999. Modeling biogas production at landfill site. Resources Conservation and Recycling, 26, pp. 1-14.

Mebarki, B.et al. 2015. Theoretical estimation of the production of biogas from the landfill of Batna city and its electrical conversion by a SOFC. International Journal of Hydrogen Energy, 40 (39), pp. 13799-13805.

Ministério da Ciência e Tecnologia (MCT). 2010. Segundo Inventário Brasileiro de Emissões Antrópicas de Gases de Efeito Estufa: Relatório de referência para as emissões de gases de efeito estufa no tratamento e eliminação de resíduos. Available at: < http://sirene.mcti.gov.br/documents/1686653/1706429/228953.pdf/8e299655-2df1-4a34-84f659ae4d887c2f > [Accessed 18 January 2016].

Ministério da Ciência Tecnologia e Inovação (MCTI). 2015. Terceiro Inventário Brasileiro das emissões e remoções antrópicas de Gases de Efeito Estufa: Relatório de referência. Setor de tratamento de resíduos. Available at: <http://sirene.mcti.gov.br/documents/1686653/1706163/RR_Tratamento+de+Res\%C3\%ADduos _III+Invent\%C3\%A1rio.pdf/a4edb776-2971-4b84-8030-153ee290fOcb> [Accessed 18 January 2016).

Min, J. E.et al. 2010. Leachate modeling for a municipal solid waste landfill for upper expansion. Environmental Engineering, 14(4), pp. 473-480.

Neto, F. et al. 2017. Assessment of positional quality in spatial data generated by VANT using point and linear feature for cadastre applications. Boletim de Ciências Geodésicas, 23 (1), pp. 134 - 149.

Renou, S. et al. 2008. Landfill leachate treatment: Review and opportunity. Journal of Hazardous Materials, 150 (3), pp. $468-493$. 
RIZOMA Engenharia e Paisagismo 2007. Projeto Executivo de Remediação e de Encerramento do "Lixão" de Volta Redonda. [CD] Brasil. 300 p.

Ruiz, L. F. C. Guasselli, L. A. and Caten, A. T. 2017. Object based analysis and decision tree for the classification of submetrical spatial resolution images captured by UAV. Boletim de Ciências Geodésicas, 23 (2), pp. $252-267$.

Santos, M. M. O. Van Elk, A. G. P. and Romanel, C. 2015. A correction in the CDM methodological tool for estimating methane emissions from solid waste disposal sites. Journal of Environmental Management, 164, pp.151-160.

Silva, C. A. et al. 2016. Evaluating the accuracy in volume calculation in a pile of waste using UAV GNSS and LiDAR. Boletim de Ciências Geodésicas, 22 (1), pp. 73 - 94.

Sistema Nacional de Informações sobre Saneamento (SNIS), 2015. Diagnóstico do manejo de Resíduos Sólidos Urbanos. Avaible at: <http://www.snis.gov.br/diagnostico-residuossolidos/diagnostico-rs-2015> [Accessed 01 April 2017].

SEDU, 2001. Manual de Gerenciamento de Resíduos Sólidos Integrado. Rio de janeiro: IBAM.

Sothe C. et al. 2017. Abordagens para classificação do estádio sucessional da vegetação do parque nacional de são Joaquim empregando imagens landsat-8 e rapideye. Boletim de Ciências Geodésicas, 3 (3), pp. 389-404.

Souza, C. G. et al. 2016. Machine learning algorithms and variable of remote sensing for coffee cropping mapping. Boletim de Ciências Geodésicas, 22 (4), pp. $751-773$.

Sil, A. Kumar, S. and Wong, J. W. C. 2014. Development of correction factors for landfill gas emission model suiting Indian condition to predict methane emission from landfills. Bioresource Technology, 168, pp.97-99.

Srivastava, V. et al. 2015. Urban solid waste management in the developing world with emphasis on India: challenges and opportunities. Reviews in Environmental Science and Biotechnology, 14 (2), pp. 317-337.

Toz G. and Endorgan, M. 2008. DEM (digital elevation model) production and accuracy modeling of dems from 1:35.000 scale aerial photographs. The International Archives of the Photogrammetry Remote Sensing and Spatial Information Sciences 37 part. B1 pp. 775 - 780.

USEPA, 2005. Landfill Gas Emissions Model (LandGEM) Version 3.02 User's Guide. Available at: <https://www3.epa.gov/ttncatc1/dir1/landgem-v302-guide.pdf> [Accessed 25 April 2016].

World Bank, 2004. Handbook for the preparation of landfill gas to energy projects in Latin America and the Caribbean. Ontario: Conestoga-Rovers \& Associates.

Wu, D. et al. 2015. Perspective of harnessing energy from landfill leachate via microbial fuel cells: novel biofuels and electrogenic physiologies. Applied Microbiology Biotechnology, 99 (19), pp. 7827-7836.

Xiao, Y.et al. 2017. A comparison of haze removal algorithms and their impacts on classification accuracy for landsat imagery. Boletim de Ciências Geodésicas, 23 (1), pp. 55 - 71.

Zacharof, A. I. Butler, A. P. 2004. Stochastic modelling of landfill processes incorporating waste heterogeneity and data uncertainty. Waste Management, 24, pp. 241-250. 
Zairi, M. Aydi, A. and Dhia, H. N. 2014. Leachate generation and biogas energy recovery in the Jebel Chakir municipal solid waste landfill. Tunisia. Journal of Material Cycles and Waste Management, 16(1), pp. 141-150. 